\title{
ІНФЛАМАТОМЕТРИЧНІ ОСОБЛИВОСТІ ПЕРЕБІГУ БРОНХІАЛЬНОЇ АСТМИ ЗА РІЗНОГО СТУПЕНЯ АКТИВНОСТІ ЕОЗИНОФІЛЬНОГО ЗАПАЛЕННЯ ДИХАЛЬНИХ ШЛЯХІВ
}

Вищий державний навчальний заклад України «Буковинський державний медичний університет», м. Чернівці

Резюме. Обстежено 76 дітей шкільного віку, хворих на персистувальну бронхіальну астму, які отримували як протизапальну базисну терапію інгаляційні глюкокортикостероїди не менше трьох останніх місяців та потребували корекції обсягу профілактичного лікування. Виявлено, що у дітей, хворих на бронхіальну астму, посилена дегрануляція еозинофілів мокротиння (за вмістом еозинофільного катіонного білка) асоціює 3 виразнішим запальним процесом у бронхах, про що

Вступ. Бронхіальна астма (БА), попри значний прогрес у розумінні патофізіологічних механізмів та впровадження в практику чітких стандартів лікування та контролю за їх ефективністю, залишається значною медико-соціальною проблемою. Неухильне зростання її розповсюдженості, особливо в дитячому віці, відсутність позитивної динаміки в зменшенні рівня інвалідності та летальності [4], підкреслюють недостатню ефективність менеджменту цієї недуги. У 80 \% випадків захворювання формується в дитячому віці [1, 7], тому є найбільш поширеною хронічною патологією даного вікового періоду.

Актуальним наразі є питання більш індивідуалізованого підходу до лікування та профілактики захворювання, із розширенням меж існуючої клініко-інструментальної класифікації захворювання [6, 9]. 3 цієї позиції, урахування індивідуальних клініко-анамнестичних даних, характеру запалення бронхіального дерева, показників гіперсприйнятливості дихальних шляхів, імунологічного профілю, функцій клітин, що беруть участь в алергічному запаленні, які в комплексі визначають гетерогенність бронхіальної астми [12], може вважатися перспективним щодо вдосконалення індивідуальних лікувально-профілактичних заходів, котрі представляють актуальну задачу наукової і практичної педіатрії та алергології.

Оскільки бронхіальна астма представляє хронічний запальний процес дихальних шляхів, то запальні клітини в ньому відіграють центральну роль [3], визначаючи клінічну виразність захворювання, особливості його патогенезу, шляхи оптимізації та полегшення персистування бронхіальної гіперреактивності. Почасти клітинний склад запального інфільтрату дихальних шляхів характеризується збільшенням числа активованих еозинофілів, нейтрофілів, тучних клітин, моноцитів [8]. Не викликають сумніву кореляційні зв'язки між наявністю активованих еозинофілів, гістологічними змінами та розвитком гіперреактивності дихальних шляхів [5]. Після накопичен-

(C) О.К. Колоскова, Т.О. Лобанова, 2016 свідчать підвищена інтенсивність окисної модифікації

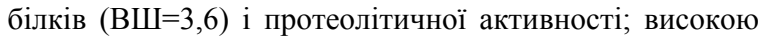
активністю каталази; зростанням вмісту VEGF як маркера ремоделювання бронхів, а також зі зменшенням вмісту метаболітів монооксиду нітрогену в конденсаті видихуваного повітря.

Ключові слова: бронхіальна астма, діти, еозинофільне запалення.

ня у шок-органі алергічного запалення, дані клітини продукують цілу низку медіаторів запалення (наприклад, фактор активації тромбоцитів, лейкотриєни, простагландини, гістамін, цитокіни, хемокіни і катіонні білки), які посилюють запальну реакцію дихальних шляхів, підтримують їх гіперсприйнятливість до специфічних і неспецифічних стимулів, викликають пошкодження тканин, їх дисфункцію та органічну перебудову (ремоделювання) [10].

Одним із чотирьох основних протеїнів, що міститься у гранулах еозинофілів, $\epsilon$ еозинофільний катіонний білок, визнаний одним із маркерів еозинофіл-опосередкованого запального процесу при БА. Це одноланцюговий, цинковмісний протеїн із молекулярною масою в межах від 16 до 22 кДа, який володіє цитотоксичним потенціалом щодо створення пор у клітинних мембранах, зокрема бактерій, паразитів, вірусів й епітелію дихальних шляхів. Даний протеїн стимулює секрецію слизу залозами дихальних шляхів і вивільнення гістаміну базофілами та тучними клітинами in vitro. Тригерами вивільнення еозинофілами еозинофільного катіонного протеїну виступають імуноглобулін $\mathrm{G}$ та інтерлейкін-5. Важливо, що в експерименті не доведена можливість терапевтичних доз глюкокортикостероїдів пригнічувати викид еозинофільного катіонного білка [11].

Мета дослідження. Для вдосконалення лікувально-профілактичних заходів при бронхіальній астмі у дітей дослідити клінічне значення вмісту еозинофільного катіонного протеїну в мокротинні та його діагностичну роль у менеджменті захворювання.

Матеріал і методи. В умовах обласного пульмоалергологічного стаціонару обстежено 76 дітей шкільного віку, хворих на персистувальну бронхіальну астму, які отримували інгаляційні глюкокортикостероїди (ІГКС) як протизапальну базисну терапію впродовж не менше трьох останніх місяців, та потребували корекції обсягу профілактичного лікування. Усім обстеженим у позанападному періоді здійснювали забір мокро- 
тиння для подальшого аналізу, причому за відсутності спонтанного відкашлювання здійснювали процедуру індукції відходження мокротиння шляхом інгаляції серійних гіпертонічних розчинів натрію хлориду.

У мокротинні визначали кількісний та якісний цитологічний склад осаду, а в надосадовій рідкій фракції, отриманій після центрифугування, за допомогою ELISA-методу визначали вміст еозинофільного катіонного білка (human eosinophil cationic protein - ECP, виробник реактивів Aviscera Bioscience, Inc, USA) та методом ІФА концентрацію ендотеліального фактору росту судин (VEGF) (реагенти “ИФА-Бест”, виробництва „Вектор-Бест, РФ).

Середній вміст ЕСР становив 2,28 22,2 нг/мл (мінімальне значення 0, максимальне - 9,2 нг/мл). Залежно від вмісту ЕСР у мокротинні дітей розподіляли на дві клінічні групи. До першої (основної) увійшли 29 дітей із вмістом у мокротинні ЕСР більше середньо-групового значення, а решта обстежених - до II групи (порівняння), оскільки концентрація ЕСР у їх мокротинні не перевищувала 2,3 нг/мл. За основними клінічними характеристиками групи були зіставимі (табл. 1).

Проводили біохімічне дослідження конденсату видихуваного повітря, що передбачало визначення вмісту загального білка за методом Lowry O.H., активності каталази за Королюк М.А. та співавт.; концентрації метаболітів монооксиду нітрогену за Смченко Н.Л.; маркери протеолітичної активності за лізисом азоальбуміну, азоказеїну та азоколагену за Веремєєнком К.Н. та співавт., а також сумарної, ферментативної та неферментативної фібринолітичної активності за методикою Кухарчука О.Л. [2].

Одержані результати дослідження аналізували за допомогою комп'ютерних пакетів
«STATISTICA 6.0» StatSoft Inc. та Excel XP для Windows на персональному комп'ютері з використанням параметричних і непараметричних методів обчислення.

Результати дослідження та їх обговорення. У роботі показано, що в групах порівняння збігалися клінічні показники контролю БА $(18,3 \pm 1,5$ проти $18,6 \pm 1,3$ бала, $\mathrm{P}>0,05)$, клітинного складу мокротиння, зокрема за кількістю еозинофільних гранулоцитів $(9,24 \pm 2,3$ проти 9,28 $\pm 2,2 \%, \mathrm{P}>0,05)$.

У загальній когорті хворих результати вивчення вмісту VEGF у надосадовій рідині мокротиння розподілилися таким чином: у 26 дітей він не перевищував 60 пг/мл, у 20 хворих був у межах 60-119 пг/мл, а у решти школярів сягав 120 пг/мл і вище. При цьому, вміст у мокротинні VEGF, який відображує стан процесів ремоделювання бронхів, у 1,25 раза був вищим у представників I групи $(145,43 \pm 19,71)$ пг/мл порівняно 3 хворими II групи $(115,93 \pm 15,7)$ пг/мл $(\mathrm{P}>0,05)$.

У таблиці 2 наведені показники окисної модифікації білків й активність каталази в конденсаті видихуваного повітря.

Попри відсутність статистично вірогідних відмінностей у середніх показниках виразності запального процесу в бронхах, вони асоціювали 3 активністю дегрануляції еозинофілів мокротиння, яку відображував вміст ЕСР у надосадовій рідині. Так, вміст ЕСР більше 2,0 нг/мл як тест, що відображував посилену пероксидацію протеїнів дихальних шляхів, характеризувався наступними показниками діагностичної цінності: чутливість (ЧТ) - 78,3 \% (95 \% ДІ: 56,3-92,5), специфічність (СТ) - 50,0 \% (95 \% ДІ: 28,2-71,8), передбачувана цінність позитивного результату (ПЦПР) - 62,1 \% (95 \% ДІ: 42,3-79,3) і негативного тесту (ПЦНР) - 68,8 \% (95 \% ДІ: 41,3-89,0). При цьому посттестова вірогідність при позитивному результаті тесту зростала на $11,02 \%$, а при

Таблиця 1

Загальна клінічна характеристика груп порівняння $(\mathrm{P} \pm \mathbf{m})$

\begin{tabular}{|c|c|c|c|c|c|}
\hline Клінічні групи & $\begin{array}{c}\text { Кількість } \\
\text { дітей }\end{array}$ & Хлопчики, \% & $\begin{array}{c}\text { Міські мешканці, } \\
\%\end{array}$ & $\begin{array}{c}\text { Середній вік, } \\
\text { роки }\end{array}$ & $\begin{array}{c}\text { Тривалість хворо- } \\
\text { би, роки }\end{array}$ \\
\hline I група & 29 & $64,3 \pm 7,4$ & $50,0 \pm 7,7$ & $11,7 \pm 0,6$ & $4,5 \pm 0,6$ \\
\hline II група & 47 & $63,4 \pm 7,5$ & $41,5 \pm 7,7$ & $12,0 \pm 0,5$ & $5,9 \pm 0,7$ \\
\hline \multicolumn{5}{|c|}{ P } & \multicolumn{5}{|c|}{$>0,05$} \\
\hline
\end{tabular}

Таблиця 2

Вміст продуктів окиснювальної модифікації білків у конденсаті видихуваного повітря дітей груп порівняння (M土m)

\begin{tabular}{|c|c|c|c|c|c|}
\hline \multirow{2}{*}{$\begin{array}{c}\text { Клінічні } \\
\text { групи }\end{array}$} & \multirow{2}{*}{$\begin{array}{c}\text { К-сть } \\
\text { дітей }\end{array}$} & $\begin{array}{c}\text { Продукти окиснювальної модифікації білків } \\
\text { теру, Е 430 } \\
\text { ммоль / г білка }\end{array}$ & $\begin{array}{c}\text { нейтрального характе- } \\
\text { ру, Е 370 ммоль / } \\
\text { білка }\end{array}$ & $\begin{array}{c}\text { Вміст загально- } \\
\text { го білка, г/л }\end{array}$ & $\begin{array}{c}\text { Активність ката- } \\
\text { лази, мкмоль / хв } \\
\text { х мг білка }\end{array}$ \\
\hline I група & 19 & $75,4 \pm 18,8$ & $8,2 \pm 2,6$ & $4,13 \pm 0,78$ & $68,4 \pm 22,6$ \\
\hline II група & 31 & $62,1 \pm 12,5$ & $6,5 \pm 1,2$ & $3,71 \pm 0,4$ & $49,6 \pm 10,3$ \\
\hline \multicolumn{2}{|c|}{ P } & \multicolumn{4}{|c|}{$>0,05$} \\
\hline
\end{tabular}

Примітка: $\mathrm{P}$ - критерій вірогідності відмінностей за Стьюдентом 
Таблиця 3

Протеолітична активність (у мл/год) у конденсаті видихуваного повітря в обстежених дітей $(\mathrm{M} \pm \mathbf{m})$

\begin{tabular}{|c|c|c|c|c|}
\hline Клінічні групи & $\begin{array}{c}\text { К-сть } \\
\text { дітей }\end{array}$ & $\begin{array}{c}\text { ПЛА за лізисом } \\
\text { азоальбуміну }\end{array}$ & $\begin{array}{c}\text { ПЛА за лізисом } \\
\text { азоказеїну }\end{array}$ \\
\hline І група & 19 & $2,0 \pm 0,43$ & $1,5 \pm 0,15$ & $0,28 \pm 0,11$ \\
\hline II група & 30 & $1,5 \pm 0,06$ & $1,3 \pm 0,07$ & $0,2 \pm 0,02$ \\
\hline \multicolumn{2}{|c|}{ Р } & \multicolumn{3}{|c|}{$>0,05$} \\
\hline
\end{tabular}

Примітка. Р - критерій вірогідності відмінностей за Стьюдентом; ПЛА - протеолітична активність

від'ємному результаті знижувалася на 20,0\%. При цьому показнику вмісту ЕСР у мокротинні зростав клінічно-епідеміологічний ризик виразної окиснювальної модифікації білків: відношення шансів - 3,6 (95 \% ДІ: 1,0-13,2), відносний ризик - 2,0 (95 \% ДІ: 1,3-3,2), атрибутивний ризик 0,31 .

У конденсаті видихуваного повітря вміст метаболітів монооксиду нітрогену (MМOH) виявився вищим у дітей II групи: 44,4 $\pm 5,74$ мкмоль/ л порівняно 3 представникам I групи 55,8 $\pm 9,8$ мкмоль/л $(\mathrm{P}>0,05)$, хоча діагностичною цінністю даний тест не володів. Водночас показники протеолітичної активності КВП підтвердили тенденцію до посилення у хворих на БА з підвищеним вмістом ЕСР (табл. 3).

Отже, попри відсутність статистично значимих розбіжностей у вивчених показниках протеолітичної активності, варто зазначити, що виявлена тенденція збігалася 3 групоформувальною ознакою, закономірностями в окисній модифікації білків та підвищеній активності каталази, а також зменшеному вмісті ММОН, що в сукупності підкреслювало вагомість еозинофільного запального процесу в дихальних шляхах обстежених хворих.

Проведений кореляційний аналіз також підтвердив виявлені закономірності й дозволив встановити окремі відмінності в інфламатометричних показниках дітей груп порівняння. Так, у групі дітей із підвищеним вмістом ЕСР (І група) активність запалення визначалася переважно пероксидацією білків ( $\mathrm{r}=0,87, \mathrm{P}<0,05)$, а також зниженням вмісту ММОН у КВП на тлі посилення лізису азоколу ( $\mathrm{r}=-0,98, \mathrm{P}<0,05)$. На противагу цьому, у II групі запальний процес зумовлювався лізисом низькомолекулярних білків $(\mathrm{r}=0,63, \mathrm{P}<0,05)$.

\section{Висновок}

Таким чином, у дітей, хворих на бронхіальну астму, посилена дегрануляція еозинофілів мокротиння (за вмістом ЕСР) асоціює 3 виразнішим запальним процесом у бронхах, про що свідчать підвищена інтенсивність окисної модифікації

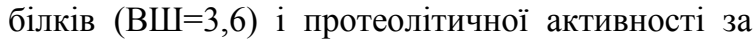
лізисом великомолекулярних протеїнів; 3 високою активністю каталази; зростанням вмісту VEGF як маркера ремоделювання бронхів, а також зі зменшенням вмісту метаболітів монооксиду нітрогену у КВП. Проте варто зауважити, що на рівневі контролю бронхіальної астми та змінах у клітинному складі мокротиння дані інфламатометричні закономірності не відзначалися.

Перспективи подальших досліджень. Полягають у вивченні інфламатометричних показників при еозинофільному запаленні дихальних шляхів у дітей із бронхіальною астмою, залежно від обсягу та тривалості базисного протизапального лікування.

\section{Література}

1. Бронхиальная астма у детей. Стратегия лечения и профилактика / [Нац. программа / науч. ред. проф. Геппе Н.А. и др.] - М.: Издательский дом «Русский врач», 2006. - 100 с.

2. Сучасні методики експериментальних та клінічних досліджень центральної науково-дослідної лабораторії БДМА / [Магаляс В.М., Михєєв А.О., Роговий Ю.Є. та ін.]. - Чернівці: БДМА, 2001. - 42 с.

3. Airway inflammation assessed by invasive and noninvasive means in severe asthma: eosinophilic and noneosinophilic asthma / C. Lemiere, P. Ernst, R. Olivenstein [et al.] // J. Allergy Clin. Immunol. - 2006. - Vol. 118, № 5. - P. 1033-1039.

4. Continued increase in the prevalence of asthma and atopy / S.H. Downs, G.B. Marks, E.G. Belosouva [et al.] // Arch. Dis. Child. - 2001. - Vol. 84. - P. 20-23.

5. Correlation between Eosinophil Count and Methacholine Challenge Test in Asymptomatic Subjects / N. Schwartz, A. Grossman, Y. Levy [et al.] // Journal of Asthma. 2012. - Vol. 49, № 4. - P. 336-341.

6. Green R.H. The reclassification of asthma based on subphenotypes / R.H. Green, C.E. Brightling, P. Bradding // Curr. Opin. Allergy Clin. Immunol. - 2007. - Vol. 7, № 1. - P. 43-50.

7. Gupta V. Bronchial asthma / V. Gupta, P. Suri // JK-Practitioner. - 2003. - Vol. 10, № 1. - P. 57-60.

8. Inflammatory and Effector Cells/Cell Migration / In: Pediatric Allergy: Principles and Practice (Third Edition): B.P. Davis, M.E. Rothenberg. - Cincinnati, Ohio. 2016. - P. 41-53.

9. Reed C.E. What the $21^{\text {st }}$ century does not know about asthma - yet / C.E. Reed // J. Allergy Clin. Immunol. 2008. - Vol. 121. - P. 601-602.

10. Slade D.J. Airway Remodeling from Bench to Bedside: Current Perspectives / D.J. Slade, M. Kraft // Clinics in Chest Medicine. - 2006. - Vol. 27, Iss. 1. - P. 71-85.

11. The inflammatory marker serum eosinophil cationic protein (ECP) compared with EF as a tool to decide inhaled corticosteroid dose in asthmatic patients / O. Lowhagen, A.M. Wever, M. Lusuardi [et al.] // Respir. Med. 2002. - Vol. 96 (2). - P. 95-101.

12. Wenzel S.E. Phenotypes in asthma / S.E. Wenzel // Am. J. Respire. Crit. Care Med. - 2004. - Vol. 170. - P. 579-582. 


\section{ИНФЛАМАТОМЕТРИЧЕСКИЕ ОСОБЕННОСТИ БРОНХИАЛЬНОЙ АСТМЫ ПРИ РАЗЛИЧНОЙ СТЕПЕНИ АКТИВНОСТИ ЭОЗИНОФИЛЬНОГО ВОСПАЛЕНИЯ ДЫХАТЕЛЬНЫХ ПУТЕЙ}

\section{Е.К. Колоскова, Т.А. Лобанова}

Резюме. Обследовано 76 детей школьного возраста, больных персистирующей бронхиальной астмой, которые получали в качестве противовоспалительной базисной терапии ингаляционные глюкокортикостероиды не меньше трех последних месяцев и требовали коррекции объема профилактического лечения. Выявлено, что у детей, страдающих бронхиальной астмой, усилена дегрануляция эозинофилов мокроты (по содержанию эозинофильного катионного белка) ассоциирует с более выраженным воспалительным процессом в бронхах (про что свидетельствует повышенная интенсивность окислительной модификации белков $(\mathrm{OШ}=3,6)$ и протеолитической активности); высокой активностью каталазы; увеличением содержания VEGF как маркера ремоделирования бронхов, а также с уменьшением содержания метаболитов монооксида нитрогена в конденсате выдыхаемого воздуха.

Ключевые слова: бронхиальная астма, дети, эозинофильное воспаление.

\section{INFLAMMATOMETRIC FEATURES OF BRONCHIAL ASTHMA IN DIFFERENT ACTIVITY OF EOSINOPHILIC INFLAMATION OF AIRWAYS}

\section{O.K. Koloskova, T.O. Lobanova}

Abstract. The study involved 76 schoolchildren suffering from persistent asthma treated by inhaled glucocorticosteroids as anti-inflamatory basic therapy during at least the last three months and needed a correction of preventive treatment amount. It was established that in children with asthma, increased sputum eosinophil degranulation (the content of eosinophilic cationic protein) associates with expressive inflammation in the bronchi, as evidenced by the increased intensity of oxidative modification of proteins $(\mathrm{OR}=3,6)$ and proteolytic activity; high activity of catalase; growing content of VEGF as a marker of bronchial simulation, as well as with decreasing nitrogen monoxide content of metabolites in exhaled condensate.

Key words: bronchial asthma, children, eosinophilic inflammation.

Higher State Educational Institution of Ukraine "Bukovinian State Medical University" (Chernivtsi) 